\title{
CHARACTERIZATION OF FREE NITROGEN FIXING BACTERIA OF THE GENUS Azotobacter IN ORGANIC VEGETABLE-GROWN COLOMBIAN SOILS
}

\author{
Diego Javier Jiménez ${ }^{1}$; José Salvador Montaña ${ }^{1 *}$; María Mercedes Martínez ${ }^{2}$ \\ ${ }^{1}$ Department of Microbiology, Faculty of Sciences, Pontificia Universidad Javeriana, Bogotá, D.C., Colombia ${ }^{\text {th }}$ Avenue 43-82, \\ Building 50, Lab.106, Tel. 57-1-3208320 Ext. 4173, Bogotá, D.C., Colombia; ${ }^{2}$ Institute of Crop Science and Resource \\ Conservation, Faculty of Agriculture, University of Bonn, Bonn, Germany, Auf dem Hugel 6, 53121.
}

Submitted: June 18, 2010; Returned to authors for corrections: January 13, 2011; Approved: March 14, 2011.

\begin{abstract}
With the purpose of isolating and characterizing free nitrogen fixing bacteria (FNFB) of the genus Azotobacter, soil samples were collected randomly from different vegetable organic cultures with neutral $\mathrm{pH}$ in different zones of Boyacá-Colombia. Isolations were done in selective free nitrogen Ashby-Sucrose agar obtaining a recovery of $40 \%$. Twenty four isolates were evaluated for colony and cellular morphology, pigment production and metabolic activities. Molecular characterization was carried out using amplified ribosomal DNA restriction analysis (ARDRA). After digestion of 16S rDNA Y1-Y3 PCR products (1487pb) with AluI, HpaII and RsaI endonucleases, a polymorphism of $16 \%$ was obtained. Cluster analysis showed three main groups based on DNA fingerprints. Comparison between ribotypes generated by isolates and in silico restriction of $16 \mathrm{~S}$ rDNA partial sequences with same restriction enzymes was done with Gen Workbench v.2.2.4 software. Nevertheless, Y1-Y2 PCR products were analysed using BLASTn. Isolate C5T from tomato (Lycopersicon esculentum) grown soils presented the same in silico restriction patterns with $A$. chroococcum (AY353708) and 99\% of similarity with the same sequence. Isolate C5CO from cauliflower (Brassica oleracea var. botrytis) grown soils showed black pigmentation in Ashby-Benzoate agar and high similarity (91\%) with A. nigricans (AB175651) sequence. In this work we demonstrated the utility of molecular techniques and bioinformatics tools as a support to conventional techniques in characterization of the genus Azotobacter from vegetable-grown soils.
\end{abstract}

Key words: ARDRA; Azotobacter; FNFB; UPGMA.

\section{INTRODUCTION}

The genus Azotobacter belongs to the $\gamma$-subclass of the Proteobacteria (4, 34) and comprises seven species: $A$. chroococcum, A. vinelandii, A. beijerinckii, A. paspali, A. armeniacus, A. nigricans and A. salinestri. In 2005 sequences of $16 \mathrm{~S}$ rDNA were identified that corresponded to a new endemic soil species from Thailand (unpublished data). Azotobacter are heterotrophic and aerobic bacteria and their main property is the ability to fix nitrogen non-symbiotically, with a genomic content of G-C of $63-67.5 \%\left(\mathrm{~T}_{\mathrm{m}}\right)(4,32)$, and distributed in soils, water and sediments $(35,36)$. Their

*Corresponding Author. Mailing address: Department of Microbiology, Faculty of Sciences, Pontificia Universidad Javeriana, Bogotá, D.C., Colombia $7^{\text {th }}$ Avenue 43-82, Building 50, Lab.106, Tel. 57-1-3208320 Ext. 4173, Bogotá, D.C., Colombia.; Tel.: 49-228-735135.; E-mail: jose.montana@javeriana.edu.co 
agronomic importance is due to the capability of synthesizing antibiotics, plant growth promotion substances $(21,24,25,30)$, vitamins, exopolysaccharides and pigment production $(8,28)$, besides their antagonist effect against pathogens (33). They also have the ability to solubilize phosphates in aquaculture systems, vermicompost production and potato (Solanum tuberosum) grown soils $(9,12,19)$. In Colombia, it has been used as bacterial inoculants in the culture of Dendranthema grandiflora, Stevia rebaudiana, vegetables and cotton $(6,11$, 29). Characterization of Azotobacter species becomes difficult due to the morphological similarity that exists with other FNFB like Derxia, Azomonas and Beijerinckia, in addition to its interspecific biochemical ambiguity. For that reason, in the last years authors like Aquilanti et al. (1, 2), and Becking (4), among others, justify the use of molecular techniques and bioinformatics tools allowing fast identification and characterization. This interest is focused towards the validation of fast and reliable molecular methodologies for quality control on agricultural biofertilizers. In this context, amplified ribosomal DNA restriction analysis (ARDRA) was evaluated for the characterization of Azotobacter isolated from organic vegetable-grown soils, with the purpose of generating a molecular approach to this genus in Colombian agroecosystems.

\section{MATERIALS AND METHODS}

\section{Isolation and biochemical characterization}

Soil samples from organic broccoli (Brassica oleracea var. italica), zucchini (Cucurbita pepo), cauliflower (B. oleracea var. botrytis), spinach (Spinacia oleracea), tomato (Lycopersicon esculentum) and carrot (Daucus carota) grown soils were collected during October 2006 in Sogamoso $\left(5^{\circ} 43^{\prime} \mathrm{N}, 72^{\circ} 55^{\prime} \mathrm{W}\right)$ and Tibasosa $\left(5^{\circ} 44^{\prime} \mathrm{N}, 73^{\circ} 00^{\prime} \mathrm{W}\right)$ (BoyacáColombia) (Table 1). Five random samples each of $500 \mathrm{~g}$ were withdrawn from 10-15 cm depth and sieved through a 4.75 mm-mesh sieve. Soil $\mathrm{pH}$ was measured according to Van
Lierop (38), analyzing samples fully suspended in distilled water 1:1 (v/v). The primary isolation was made using the grain soil technique (Figure 1A) according to the methodology previously described by Aquilanti et al. (1) and Becking (4) in Ashby-Sucrose agar (Agar 1.5\%, Sucrose 0.5\%, $\mathrm{CaCO}_{3} 0.5 \%$, $\mathrm{MgSO}_{4} 0.02 \%, \mathrm{NaCl} 0.02 \%, \mathrm{KH}_{2} \mathrm{PO}_{4} 0.02 \%, \mathrm{FeSO}_{4} 0.0005 \%$ ). Plates were incubated at $28^{\circ} \mathrm{C}$ for 7 days until observing sticky and glistening colonies around grains (Figure 1F). Counts were made for each cultivated soil $(\%$ Recovery $=$ Number of grains with sticky and glistening colonies/total x 100). Isolates were purified by streaking on free nitrogen Ashby-Sucrose agar and morphological observations were done and subsequently stored at $-80^{\circ} \mathrm{C}$ in nutrient broth $\left(\right.$ Scharlau $^{\circledR}$, Barcelona, Spain) containing 50\% glycerol. Pigment production was observed by growing the cultures in Ashby agar with $0.5 \%(\mathrm{w} / \mathrm{v})$ of Benzoate $(4,22)$ and incubation at $28^{\circ} \mathrm{C}$ for 7 days. $A$. vinelandii ATCC12518 and Azotobacter sp. strain (CCT) previously isolated were used for biochemical identification and molecular characterization. Biochemical identification was carried out in triplicate using different sources of carbon: glucose (GLU), maltose (MAL), mannitol (MAN), ramnose (RAM) $1 \%(\mathrm{w} / \mathrm{v})$ and benzoate (BNZ) $0.5 \%(\mathrm{w} / \mathrm{v})$ in phenol red broth (Merck®, Germany). Oxidase (OXI), catalase (CAT) and nitrate reduction tests were done (34) and biochemical sets were incubated at $28^{\circ} \mathrm{C}$ and evaluated after $24 \mathrm{~h}$.

\section{Genomic DNA extraction}

Cultures were grown overnight in $5 \mathrm{ml}$ nutrient broth, shaked at $150 \mathrm{rpm}$ and $20^{\circ} \mathrm{C}$ for $48 \mathrm{~h}$. A $1.5 \mathrm{ml}$ of the culture was centrifuged at $10000 \mathrm{~g}$ for $2 \mathrm{~min}$ and the resultant pellet was resuspended in $1050 \mu \mathrm{l}$ X TE buffer (10 mM Tris-HCl, 1 $\mathrm{mM}$ EDTA) and centrifuged at $10000 \mathrm{~g}$ for $2 \mathrm{~min}$, resuspended again in $350 \mu \mathrm{l} 1 \mathrm{X}$ TE buffer, $5 \mu 1$ lysozyme (50 $\mathrm{mg} / \mathrm{ml})$ and $2 \mu \mathrm{l}$ RNAse A $(10 \mathrm{mg} / \mathrm{ml})$ (Sigma ${ }^{\circledR}$, St Louis, USA), and incubated at $37^{\circ} \mathrm{C}$ for $10 \mathrm{~min}$. Finally, $3 \mu \mathrm{l}$ proteinase K $(20 \mathrm{mg} / \mathrm{ml})$ (Invitrogen $\AA$, Steinheim, Germany) and $30 \mu \mathrm{l}$ SDS $10 \%$ were added and incubated at $65^{\circ} \mathrm{C}$ for 15 
min. Crude DNA template was PCI (Phenol - Chloroform Isoamyl alcohol) (25:24:1) and CI (Chloroform - Isoamyl alcohol) (24:1) extracted, precipitated in $1 \mathrm{ml}$ absolute ethanol and washed with $500 \mu 170 \%$ ethanol and resuspended in $50 \mu 1$ of sterilized ultrapure water and stored at $-20^{\circ} \mathrm{C}$.

\section{ARDRA}

A 1487 bp fragment was amplified from the 16S rDNA gene using universal primers Y1 (5'TGGCTCAGAACGAACGCTGGCGGC-3') and Y3 (5'TACCTTGTTACGACTTCACCCCAGTC-3'). (20, 40). PCR reaction was done in a $100 \mu \mathrm{l}$ reaction mixture containing: $1 \mathrm{U}$ of Taq DNA polymerase (Biolase ${ }^{\circledR}$, Luckenwalde, Germany), $1 \mathrm{X} \mathrm{NH} \mathrm{NH}_{4}$ reaction buffer $\left(160 \mathrm{mM}\left(\mathrm{NH}_{4}\right)_{2} \mathrm{SO}_{4}, 670 \mathrm{mM}\right.$ Tris$\mathrm{HCl} \mathrm{pH} \mathrm{8.8,0.1 \%} \mathrm{Tween} \mathrm{20),} 2 \mathrm{mM}$ of $\mathrm{MgCl}_{2}, 50 \mu \mathrm{M}$ of dNTPs, $0.2 \mu \mathrm{M}$ of each primer and 50-100 ng of DNA. PCR reactions were run for 35 cycles on a My cycler $\left(\operatorname{Biorad}^{\circledR}\right.$, Hercules, CA, USA) as follows: denaturation at $93^{\circ} \mathrm{C}$ for $45 \mathrm{~s}$, annealing at $62^{\circ} \mathrm{C}$ for $45 \mathrm{~s}$, and elongation at $72^{\circ} \mathrm{C}$ for $2 \mathrm{~min}$. An initial denaturation step at $93^{\circ} \mathrm{C}$ for $2 \mathrm{~min}$ and a final extension step at $72^{\circ} \mathrm{C}$ for $5 \mathrm{~min}$ (16) were also done. DNA amplification was checked by electrophoresis of $10 \mu \mathrm{l}$ of each PCR product in a $1.0 \%(\mathrm{w} / \mathrm{v})$ agarose gel, in $1 \mathrm{X}$ TBE buffer (0.09M Tris base, 0.09M sodium borate, $2.5 \mathrm{mM}$ EDTA, $\mathrm{pH}$ 8.3) for $1 \mathrm{~h}$ at $3.2 \mathrm{~V} / \mathrm{cm}$ on a Primo Thermo EC 330 Midcell (Waltham ${ }^{\circledR}$, MA, USA). A $25 \mu$ l-aliquot of the PCR product was digested in a final volume of $40 \mu \mathrm{l}$ for $3 \mathrm{~h}$ at $37^{\circ} \mathrm{C}$ with 2.5 $\mathrm{U}$ of restriction enzyme (AluI, HpaII or RsaI), 1X reaction buffer, and $0.1 \mathrm{mg} / \mu \mathrm{l}$ of BSA, according to the manufacturer (Promega $^{\circledR}$, Madison, USA). PCR products digests were separated in a $2.5 \%(\mathrm{w} / \mathrm{v})$ agarose gel electrophoresis in $1 \mathrm{X}$ TBE buffer for $3 \mathrm{~h}$ at $3.2 \mathrm{~V} / \mathrm{cm}$ and gels were stained in ethidium bromide $0.5 \mu \mathrm{g} / \mathrm{ml}$. DNA fragments were visualized at $312 \mathrm{~nm}$ with an UV-transilluminator. Gels electronic images were captured and analysed in the Quantity One 1-D Analysis software $\left(\right.$ Biorad $^{\circledR}$, Hercules, CA, USA). For data scoring only $50 \mathrm{bp}$ fragments or highest were considered to binary data matrix built. Molecular weights of each band were determined by means of a linear regression analysis, having as reference a 100 bp ladder (Promega ${ }^{\circledR}$, Madison, USA). Genetic distance between isolates was calculated using the DICE coefficient of similarity and resulting distance matrix was used for the unweighted pair group method with arithmetic mean (UPGMA) analysis using NTSYSpc v.2.2 software for Windows (27). The consistency of each node was estimated by bootstrapping across markers (10) using 1000 pseudoreplications. In silico restriction analysis was carried out with AluI, HpaII and RsaI using partial sequences of $16 \mathrm{~S}$ rDNA obtained from the following GenBank accessions: AAY336565 (A. vinelandii); AY353708 (A. chroococcum); AJ308318 (A. paspali); AB175656 (A. salinestris); AB175655 (A. armeniacus); E F100152 (A. beijerinckii); AB175651 (A. nigricans); AF112477 (Azospirillum); AB175654 (Azomonas macrocytogenes); AJ563934 (Beijerinckia derxi); AF164045 (Burkholderia tropica); AB089482 (Derxia gummosa); AY191275 (Herbaspirillum seropedicae); AY509900 (Rhizobium leguminosarum) and AB305017 (Escherichia coli), using Gene Workbench v.2.2.4 software for Windows ${ }^{\circledR}$ $\left(\right.$ CLCbio $^{\circledR}$, Maryland, USA).

\section{Sequence analyses}

Primers Y1 (5'-TGGCTCAGAACGAACGCTGGCGGC3') and Y2 (5'-CCCACTGCTGCCTCCCGTAGGAGT-3') were used for the analysis of a $318 \mathrm{bp}$ partial sequence of $16 \mathrm{~S}$ rDNA (2). PCR reaction was done in a $100 \mu 1$ reaction mixture containing: $1 \mathrm{U}$ of Taq DNA polymerase $\left(\right.$ Biolase $^{\circledR}$, Luckenwalde, Germany), $1 \mathrm{X} \mathrm{NH}_{4}$ reaction buffer $(160 \mathrm{mM}$ $\left(\mathrm{NH}_{4}\right)_{2} \mathrm{SO}_{4}, 670 \mathrm{mM}$ Tris- $\mathrm{HCl} \mathrm{pH} 8.8,0.1 \%$ Tween 20), $2 \mathrm{mM}$ of $\mathrm{MgCl}_{2}, 200 \mu \mathrm{M}$ of dNTPs, $0.5 \mu \mathrm{M}$ of each primer and 50$100 \mathrm{ng}$ of DNA. PCR reactions were run for 35 cycles on My Cycler (Biorad ${ }^{\circledR}$, Hercules, CA, USA) as follows: denaturation at $93^{\circ} \mathrm{C}$ for $45 \mathrm{~s}$, annealing at $62^{\circ} \mathrm{C}$ for $45 \mathrm{~s}$, and elongation at $72^{\circ} \mathrm{C}$ for $2 \mathrm{~min}$. An initial denaturation step at $93^{\circ} \mathrm{C}$ for $5 \mathrm{~min}$ and a final extension step at $72^{\circ} \mathrm{C}$ for 5 min were also done. 
Amplification products were quantified using a Beckman DU 500 spectrophotometer (Fullerton®, CA, USA) and sequenced. Sequences were aligned in Combined Workbench v.3.6.1 software for Windows (CLCbio®, Maryland, USA) and compared with the data bases of GenBank using BLASTn (5).

\section{RESULTS}

\section{Morphological and biochemical identification}

The soil $\mathrm{pH}$ is within the range 6.25-7.44, which has been reported optimal for the growth of Azotobacter species (3, 4). Those $\mathrm{pH}$ values facilitated the recovery, allowing obtainment percentages between $31 \%$ and $45 \%$ for the crop fields grown with six different crops. A total of twenty-four isolates were obtained. Most isolates presented whitish (cream color), smooth, irregular, shining, 3-8mm diameter colonies; nevertheless, colonies with transparent, glistening, shining, 2-5 mm diameter also appeared. Three cell type morphologies were identified: Gram-negative bacilli short and large; Gramnegative bacilli short and small; and cysts (Figure 1). Some showed a brown pigmentation and others presented a dark brown pigmentation; a single one displayed a yellowish green pigmentation, which is a characteristic of both $A$. vinelandii and A. paspali $(2,4)$. Twelve isolates were glucose fermentation positive, six showed a doubtful result (Table 1), and twenty two were catalase positive. Isolate C5T was ramnose negative; nevertheless it presented a doubtful result for glucose fermentation. For preliminary identification (Table 1), morphological traits (cell and colony morphology) and pigment production in the Ashby-Benzoate agar were considered. Additionally, both control A. vinelandii ATCC12518 and CCT strains identities were confirmed with the same test.

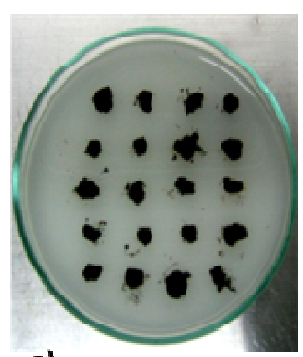

a)

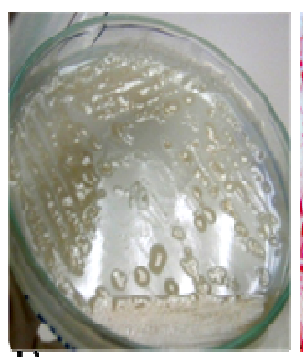

b)

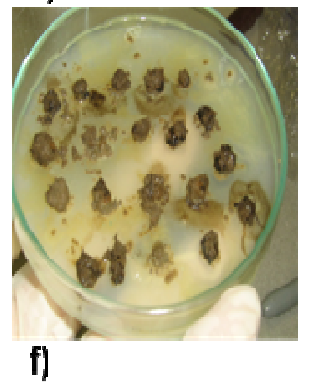

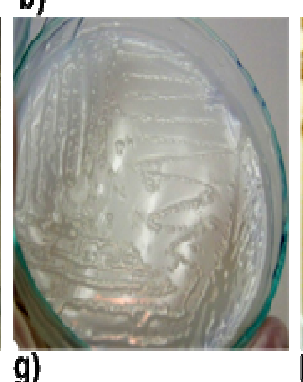

g)
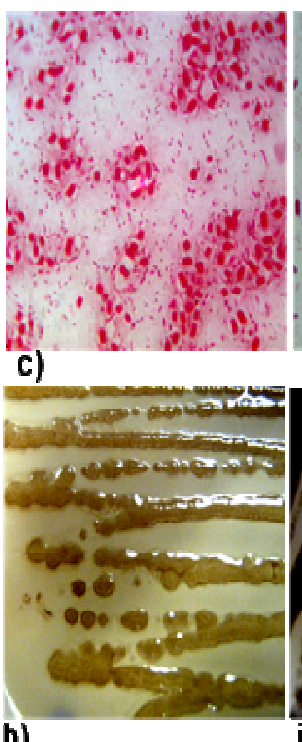

h)

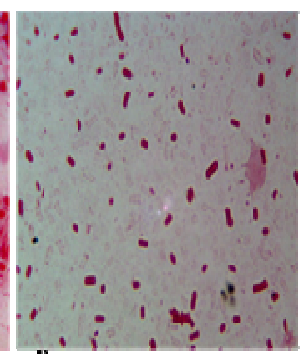

d)

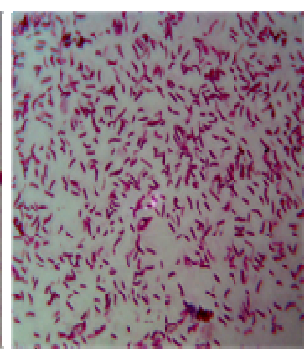

e)

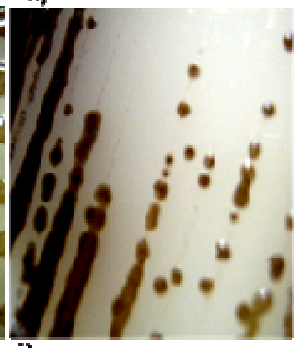

i)

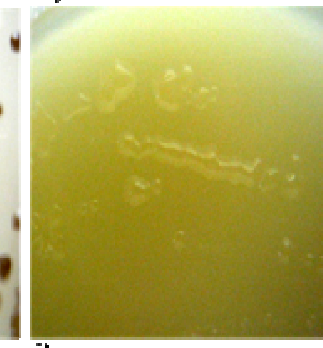

i)

Figure 1. Isolation, morphological traits and pigment production of nitrogen fixing bacteria isolates from vegetable-grown soils. a) Primary isolation using soil grain technique. b) Whitish (cream color), smooth, irregular, shining, 3-8mm in diameter colonies, isolate C5T. c) Cysts, isolate C5CA. d) Short and large Gram-negative bacilli, isolate C5T. e) Small Gram-negative bacilli isolate C1BR. f) Sticky and glistening colonies growing around soil grains g) Transparent, glistening, shining 2-5mm in diameter colonies, isolate C1BR. h) Brown pigmentation, isolate C1T. i) Brown-black pigmentation, isolate C5T. j) Yellow-green pigmentation,

C5CA. 
Table 1. Crop-grown soil samples, $\mathrm{pH}$, recovery percentage, location, morphological characteristics, biochemical and preliminary identification of nitrogen fixing bacteria isolates from vegetable-grown soils.

\begin{tabular}{|c|c|c|c|c|c|c|c|c|c|c|c|c|c|c|c|c|}
\hline Crop & pH & $\% \mathbf{R}^{\mathrm{a}}$ & Location & Isolate & $\begin{array}{c}\text { Colony } \\
\text { morphology }\end{array}$ & $\begin{array}{c}\text { Cellular } \\
\text { morphology }\end{array}$ & Pigment & $\underline{\text { GLU }}$ & $\underline{\text { MAL }}$ & $\underline{\text { MAN }}$ & $\underline{\mathbf{R A M}}$ & $\underline{\text { BNZ }}$ & $\underline{\text { OXI }}$ & CAT & NITRATE & Preliminary identification \\
\hline ND & ND & ND & ND & $\begin{array}{l}\text { ATCC } \\
12518 \\
\end{array}$ & \multirow{3}{*}{ ( 10.} & \multirow[t]{2}{*}{$\mathrm{Y}$} & \multirow{8}{*}{ NP } & + & + & + & + & $\mathrm{D}$ & + & + & \multirow{3}{*}{ NITRITE } & \multirow[t]{2}{*}{ A. vinelandii } \\
\hline Potato & ND & ND & $\mathrm{ND}$ & $\mathrm{CCT}$ & & & & + & + & + & + & + & + & + & & \\
\hline \multirow{5}{*}{ Broccoli } & \multirow{5}{*}{7.06} & \multirow{5}{*}{36.3} & \multirow{5}{*}{ Tibasosa } & C1BR & & \multirow{2}{*}{$\mathrm{X}$} & & - & - & - & - & $\mathrm{D}$ & + & - & & \multirow{2}{*}{ ND } \\
\hline & & & & C2BR & \multirow{3}{*}{ B } & & & - & + & + & $\mathrm{D}$ & - & - & + & AMMONIUM & \\
\hline & & & & C3BR & & $\mathrm{Y}$ & & + & $\mathrm{D}$ & + & - & - & + & + & NITRITE & A. nigricans \\
\hline & & & & C4BR & & $\mathrm{X}$ & & - & - & - & - & - & - & + & AMMONIUM & ND \\
\hline & & & & C5BR & \multirow{7}{*}{ A } & \multirow{2}{*}{$\mathrm{Y}$} & & $\mathrm{D}$ & + & + & + & - & + & + & NITRITE & \multirow{2}{*}{ A. vinelandii } \\
\hline \multirow{4}{*}{ Zucchini } & \multirow{4}{*}{6.82} & \multirow{4}{*}{35} & \multirow{4}{*}{ Sogamoso } & C1CA & & & & + & + & $\mathrm{D}$ & + & + & + & + & \multirow{3}{*}{ AMMONIUM } & \\
\hline & & & & C3CA & & \multirow[t]{2}{*}{ X } & $\begin{array}{l}\text { Brown- } \\
\text { Yellow }\end{array}$ & - & - & D & - & $\mathrm{D}$ & + & + & & \multirow{2}{*}{$\frac{\mathrm{ND}}{\text { A. nigricans }}$} \\
\hline & & & & C4CA & & & Brown & $\mathrm{D}$ & - & - & - & - & + & + & & \\
\hline & & & & C5CA & & Z & $\begin{array}{l}\text { Yellow- } \\
\text { Green }\end{array}$ & + & + & + & + & + & + & + & \multirow{3}{*}{ NITRITE } & A. vinelandii \\
\hline \multirow{3}{*}{ Cauliflower } & \multirow{3}{*}{7.12} & \multirow{3}{*}{33.6} & \multirow{3}{*}{ Tibasosa } & $\mathrm{C} 1 \mathrm{CO}$ & & \multirow{6}{*}{ Y } & Black & D & + & + & - & $\mathrm{D}$ & $\mathrm{D}$ & + & & $\begin{array}{l}\text { A. chroococcum/ A. } \\
\text { nigricans }\end{array}$ \\
\hline & & & & $\mathrm{C} 4 \mathrm{CO}$ & & & & $\mathrm{D}$ & - & - & - & $\mathrm{D}$ & + & + & & \\
\hline & & & & $\mathrm{C} 5 \mathrm{CO}$ & B & & NP & + & - & - & $\mathrm{D}$ & - & + & + & AMMONIUM & A. nigricans \\
\hline & & & & $\mathrm{C} 1 \mathrm{E}$ & D & & 101 & $\mathrm{D}$ & - & - & - & - & + & + & RIVIVIC & \\
\hline & & & & $\mathrm{C} 2 \mathrm{E}$ & & & & + & + & + & + & + & + & + & NITRITE & A. vinelandii \\
\hline Spinach & 6.79 & 45 & & $\begin{array}{l}\mathrm{C} 3 \mathrm{E} \\
\mathrm{C} 4 \mathrm{E}\end{array}$ & & & Brown & $\begin{array}{l}+ \\
-\end{array}$ & $\begin{array}{l}+ \\
-\end{array}$ & $\begin{array}{l}+ \\
-\end{array}$ & $\begin{array}{l}+ \\
-\end{array}$ & $\begin{array}{l}+ \\
\mathrm{D}\end{array}$ & $\begin{array}{l}+ \\
+\end{array}$ & $\begin{array}{l}+ \\
+\end{array}$ & & $\mathrm{ND}$ \\
\hline & & & & $\mathrm{C} 5 \mathrm{E}$ & A & $\mathrm{Y}$ & $\begin{array}{l}\text { Brown- } \\
\text { Black }\end{array}$ & + & $\mathrm{D}$ & + & - & $\mathrm{D}$ & $\mathrm{D}$ & + & AMMONIUM & $\begin{array}{c}\text { A. chroococcum/A. } \\
\text { nigricans }\end{array}$ \\
\hline & & & Sogamoso & $\mathrm{C} 1 \mathrm{~T}$ & & & Brown & + & - & - & - & - & + & + & & A. nigricans \\
\hline & & & & $\mathrm{C} 2 \mathrm{~T}$ & & $\mathrm{X}$ & $\mathrm{NP}$ & - & $\mathrm{D}$ & - & - & - & - & + & NITRITE & \\
\hline Tomato & 7.44 & 37.6 & & C3T & B & & $\begin{array}{c}\text { Brown- } \\
\text { Black } \\
\end{array}$ & - & - & - & - & - & + & + & AMMONIUM & ND \\
\hline & & & & $\mathrm{C} 4 \mathrm{~T}$ & & $\mathrm{Y}$ & Brown & + & + & + & + & + & + & + & NITRITE & A. vinelandii \\
\hline & & & & $\mathrm{C} 5 \mathrm{~T}$ & A & & $\begin{array}{c}\text { Brown- } \\
\text { Black }\end{array}$ & $\mathrm{D}$ & + & + & - & $\mathrm{D}$ & $\mathrm{D}$ & + & AMMONIUM & $\begin{array}{l}\text { A. chroococcum/A. } \\
\text { nigricans }\end{array}$ \\
\hline Carrot & 6.25 & 31.3 & Tibasosa & $\mathrm{C} 1 \mathrm{Z}$ & & $\mathrm{Z}$ & NP & + & - & - & - & - & - & + & NITRITE & ND \\
\hline Cantor & 0.2. & 31.0 & $110 a s u b a$ & $\mathrm{C} 2 \mathrm{Z}$ & $\mathrm{B}$ & $X$ & 101 & - & - & - & - & - & + & - & VIIIIL & A. paspali \\
\hline
\end{tabular}

${ }^{a}$ Recovery percentage; ND: Not determined; A: whitish (cream color), smooth, irregular, shining, 3-8mm in diameter colonies; B: transparent, glistening, shining, 2-5mm in diameter colonies; X: Gram-negative bacillus, short and small; Y: Gram-negative bacillus, short and large; Z: Cysts; NP: Negative pigment; (+): Positive test.; (-): Negative test; D: Doubtful; GLU: Glucose; MAL: Maltose; MAN: Mannitol; RAM: Ramnose; BNZ:

Benzoate; OXI: Oxidase test; CAT: Catalase test. 


\section{ARDRA}

Based on the preliminary identification, thirteen presumptive Azotobacter isolates (C3BR, C5BR, C1CA, $\mathrm{C} 5 \mathrm{CA}, \mathrm{C} 5 \mathrm{CO}, \mathrm{C} 1 \mathrm{E}, \mathrm{C} 2 \mathrm{E}, \mathrm{C} 3 \mathrm{E}, \mathrm{C} 5 \mathrm{E}, \mathrm{C} 1 \mathrm{~T}, \mathrm{C} 4 \mathrm{~T}, \mathrm{C} 5 \mathrm{~T}$ and $\mathrm{C} 1 \mathrm{Z})$ were selected for DNA extraction and restriction analysis. Isolate $\mathrm{C} 1 \mathrm{BR}$ was identified as not belonging to Azotobacter, therefore it was included in our study to observe genetic differences with the other isolates that were catalase positive (Table 1). A. vinelandii ATCC12518 and CCT strains were included in the molecular analysis. Restriction endonuclease $A l u \mathrm{I}$ generated eight rybotypes, a total of 78 bands and a polymorphism of $16.6 \%$; with HpaII twelve rybotypes were obtained, a total of 92 bands and a polymorphism of $17.3 \%$; and $R s a \mathrm{I}$ generated seven rybotypes, a total of 82 bands and a polymorphism of $15.8 \%$ and $1.2 \%$ of unique bands (Figure 2). UPGMA showed that the isolates exhibit three main groups (Figure 3). Group I, with a coefficient of similarity of approximately $0.75 \%$. In this group,
A. vinelandii ATCC12518 presented a greater coefficient of similarity (1.0) with respect to CCT strain and a similarity of 0.97 with respect to C5CA. Group II, with a coefficient of similarity of approximately 0.69 includes all the isolates obtained from broccoli-grown soils. Therefore, group III, with a coefficient of similarity of approximately 0.65 includes C5T, $\mathrm{C} 1 \mathrm{Z}$ and $\mathrm{C} 3 \mathrm{E}$, the ones that showed the most dissimilar restriction patterns. On the other hand, UPGMA for the in silico restriction analysis showed that Azotobacter species have similar restriction patterns except for A. chroococcum (AY353708) (Figure 4). The in silico restriction analysis with AluI generated different restriction patterns for all Azotobacter sequences and a polymorphism of $48.3 \%$. HpaII generated identical restriction patterns for A. nigricans (AB175651) and A. vinelandii (AY336565) and a polymorphism of $42.4 \%$. Finally $R s a \mathrm{I}$ generated the same restriction patterns for $A$. armeniacus (AB175655) and A. salinestris (AB175656) and a polymorphism of $50 \%$.

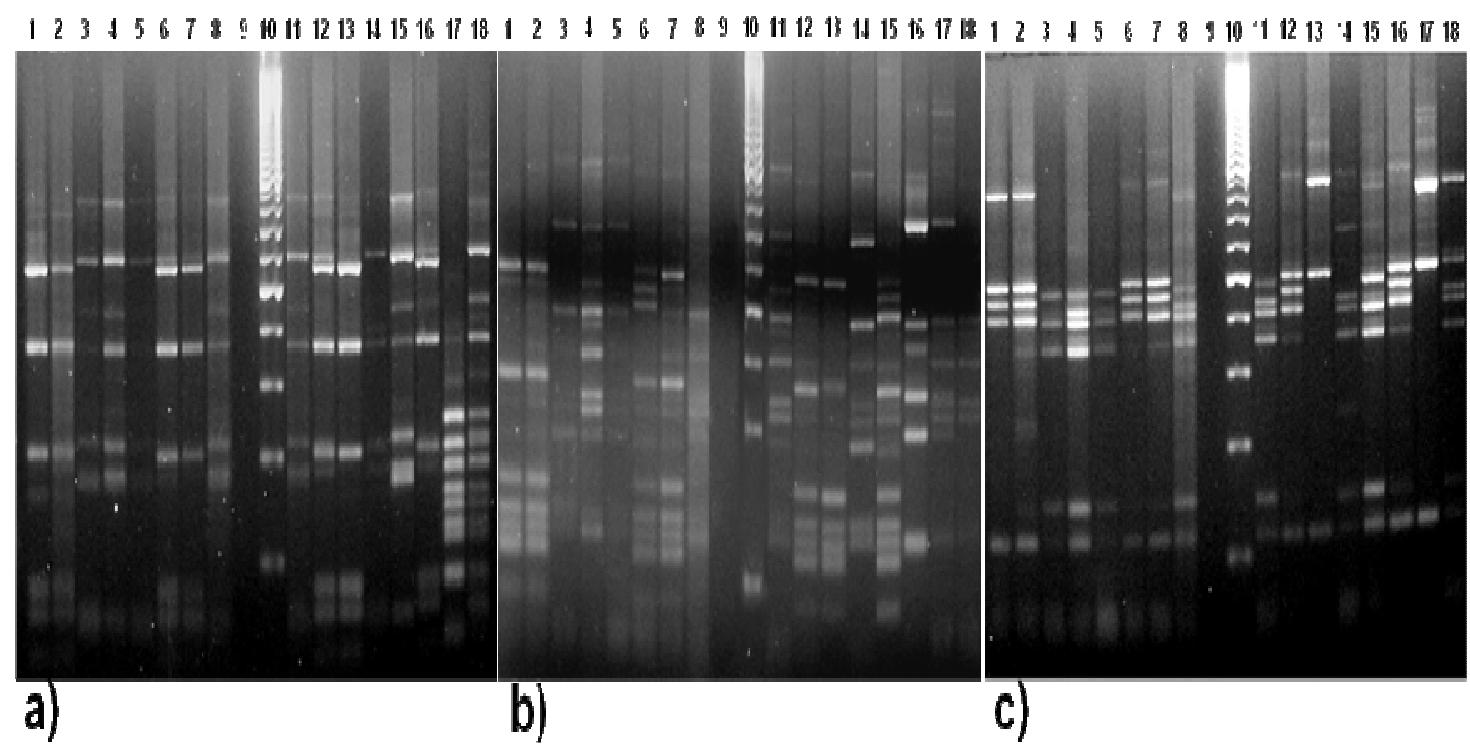

Figure 2. Agarose $2.5 \%$ gel electrophoresis of restriction fragments obtained after the digestion of 16S rDNA amplicons of nitrogen fixing bacteria isolates from vegetable-grown soils. Restriction patterns with: a) AluI. b) HpaII. c) RsaI. 1 . ATCC 12518 . 2. CCT. 3. C1BR. 4. C3BR. 5. C5BR. 6. C1CA. 7. C5CA. 8. C5CO. 9. Negative control (sterilized ultra pure water). 10. Molecular weight ladder (100pb Promega $\left.{ }^{\circledR}\right)$. 11. C1E. 12. C2E. 13. C3E. 14. C5E. 15. C1T. 16. C4T. 17. C5T. 18. C1Z. 


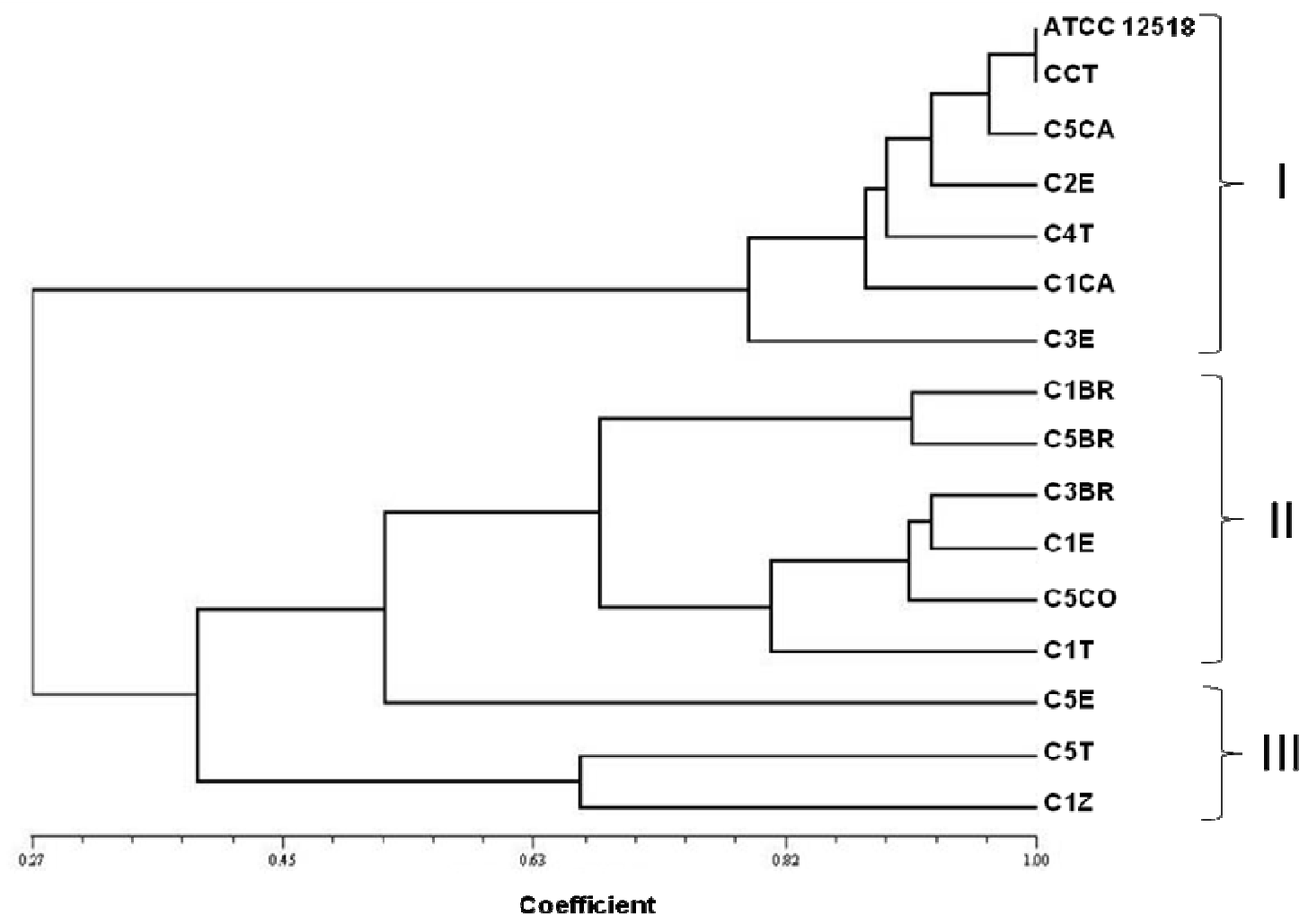

Figure 3. UPGMA for ARDRA of the FNFB isolates from vegetable-grown soils using NTSYSpc v.2.2. software for Windows ${ }^{\circledR}$.

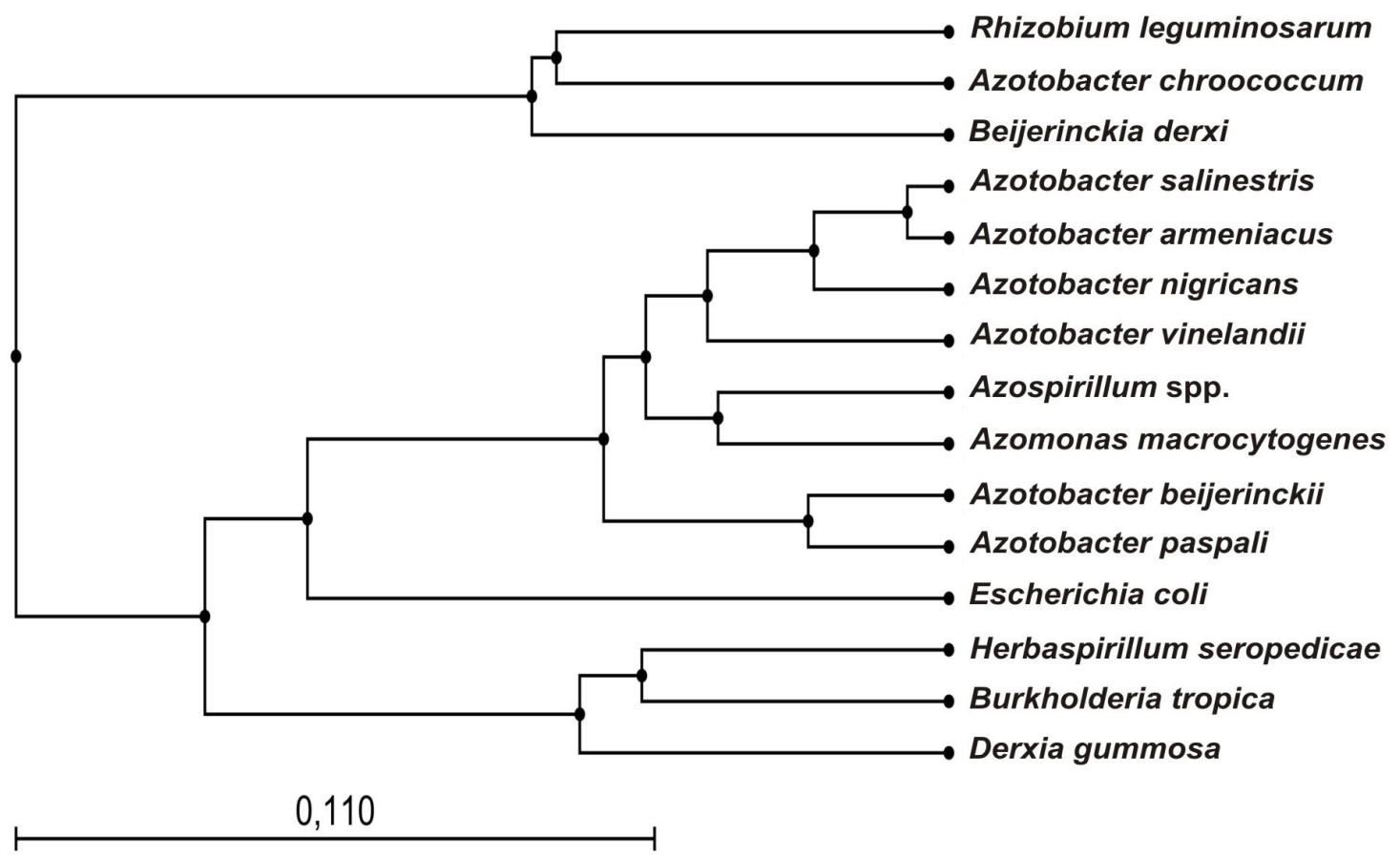

Figure 4. UPGMA for in silico restriction of the sequences of FNFB obtained from GenBank database using Gene Workbench ${ }^{\circledR}$ v.3.6.1 software for Windows ${ }^{\circledR}$. 


\section{Sequence analyses}

The dendrogram obtained after the alignment of partial $16 \mathrm{~S}$ rDNA sequences (Y1-Y2 primers) was similar to the ARDRA analysis (Figure 5). This result supports the utility of ARDRA for taxonomic classification. Isolates C1BR, C5BR and $\mathrm{C} 1 \mathrm{~T}$ are included in one group. C3BR and $\mathrm{C} 1 \mathrm{E}$ form another group, and $\mathrm{C} 5 \mathrm{CO}$ is remote. On the other hand, $\mathrm{C} 5 \mathrm{E}$, $\mathrm{C} 1 \mathrm{Z}$ and $\mathrm{C} 5 \mathrm{~T}$ form individual groups which presented dissimilar restriction patterns in ARDRA. The result of the
BLASTn (Table 2) showed that the isolates included in group I of ARDRA presented similarity with $A$. vinelandii sequences. With respect to group II of ARDRA, C1BR, C5BR and C1T presented a smaller similarity with Azotobacter sequences. Nevertheless, C5T presented a similarity of $99 \%$ with $A$. chroococcum (AY353708). The partial 16S rDNA sequences derived in this study have been deposited in GenBank (Table 2).

Table 2. Alignment of partial 16S rDNA sequences of FNFB isolates from vegetable-grown soils with sequences from databases (GenBank, EMBL and DDBJ) using BLASTn software.

\begin{tabular}{|c|c|c|c|c|}
\hline $\begin{array}{l}\text { ARDRA } \\
\text { Group }\end{array}$ & $\begin{array}{c}\text { Isolate (Accession } \\
\text { number) }\end{array}$ & Bases pairs & $\begin{array}{c}\text { Similarity } \\
(\%)\end{array}$ & $\begin{array}{c}\text { Species (Accession } \\
\text { number) }\end{array}$ \\
\hline \multirow{7}{*}{$\mathrm{I}$} & ATCC12518 (EU935082) & 307 & 79 & $\begin{array}{c}\text { Azotobacter vinelandii } \\
\text { (EF620452) }\end{array}$ \\
\hline & CCT (EU935083) & 311 & 84 & $\begin{array}{l}\text { Azotobacter vinelandii } \\
\text { (EF620451) }\end{array}$ \\
\hline & $\mathrm{C} 1 \mathrm{CA}$ & 317 & 75 & $\begin{array}{c}\text { Azotobacter vinelandii } \\
\text { (EF620439) }\end{array}$ \\
\hline & C5CA (EU935087) & 317 & 78 & $\begin{array}{c}\text { Azotobacter vinelandii } \\
\text { (EF620439) }\end{array}$ \\
\hline & $\mathrm{C} 2 \mathrm{E}$ & 318 & & NS \\
\hline & $\mathrm{C} 3 \mathrm{E}$ & 304 & 84 & $\begin{array}{c}\text { Azotobacter vinelandii } \\
\text { (EF620439) }\end{array}$ \\
\hline & $\mathrm{C} 4 \mathrm{~T}$ & 306 & 80 & $\begin{array}{c}\text { Azotobacter vinelandii } \\
\text { (EF620439) }\end{array}$ \\
\hline \multirow{6}{*}{ II } & C1BR (EU935086) & 318 & 81 & $\begin{array}{l}\text { Bacillus cereus } \\
\text { (EU368180) }\end{array}$ \\
\hline & C3BR & 315 & 89 & $\begin{array}{l}\text { Clostridium botulinum } \\
\text { (L37590) }\end{array}$ \\
\hline & C5BR & 318 & 93 & $\begin{array}{c}\text { Bacillus cereus } \\
\text { (AM711591) }\end{array}$ \\
\hline & C5CO (EU935085) & 320 & 91 & $\begin{array}{c}\text { Azotobacter nigricans } \\
(\mathrm{AB} 175651)\end{array}$ \\
\hline & $\mathrm{C} 1 \mathrm{E}$ & 320 & 79 & Azotobacter sp.(EU784140) \\
\hline & $\mathrm{C} 1 \mathrm{~T}$ & 318 & 83 & $\begin{array}{c}\text { Azotobacter sp. } \\
\text { (DQ672579) }\end{array}$ \\
\hline \multirow{3}{*}{ III } & C5E (EU935088) & 314 & 73 & $\begin{array}{c}\text { Azotobacter chroococcum } \\
\text { (EU647694) }\end{array}$ \\
\hline & C5T (EU935084) & 312 & 99 & $\begin{array}{c}\text { Azotobacter chroococcum } \\
\text { (AY353708) }\end{array}$ \\
\hline & $\mathrm{C} 1 \mathrm{Z}$ & 294 & 79 & $\begin{array}{l}\text { Azotobacter sp. } \\
\text { (DQ672579) }\end{array}$ \\
\hline
\end{tabular}

NS: No similarity with any reported sequence 


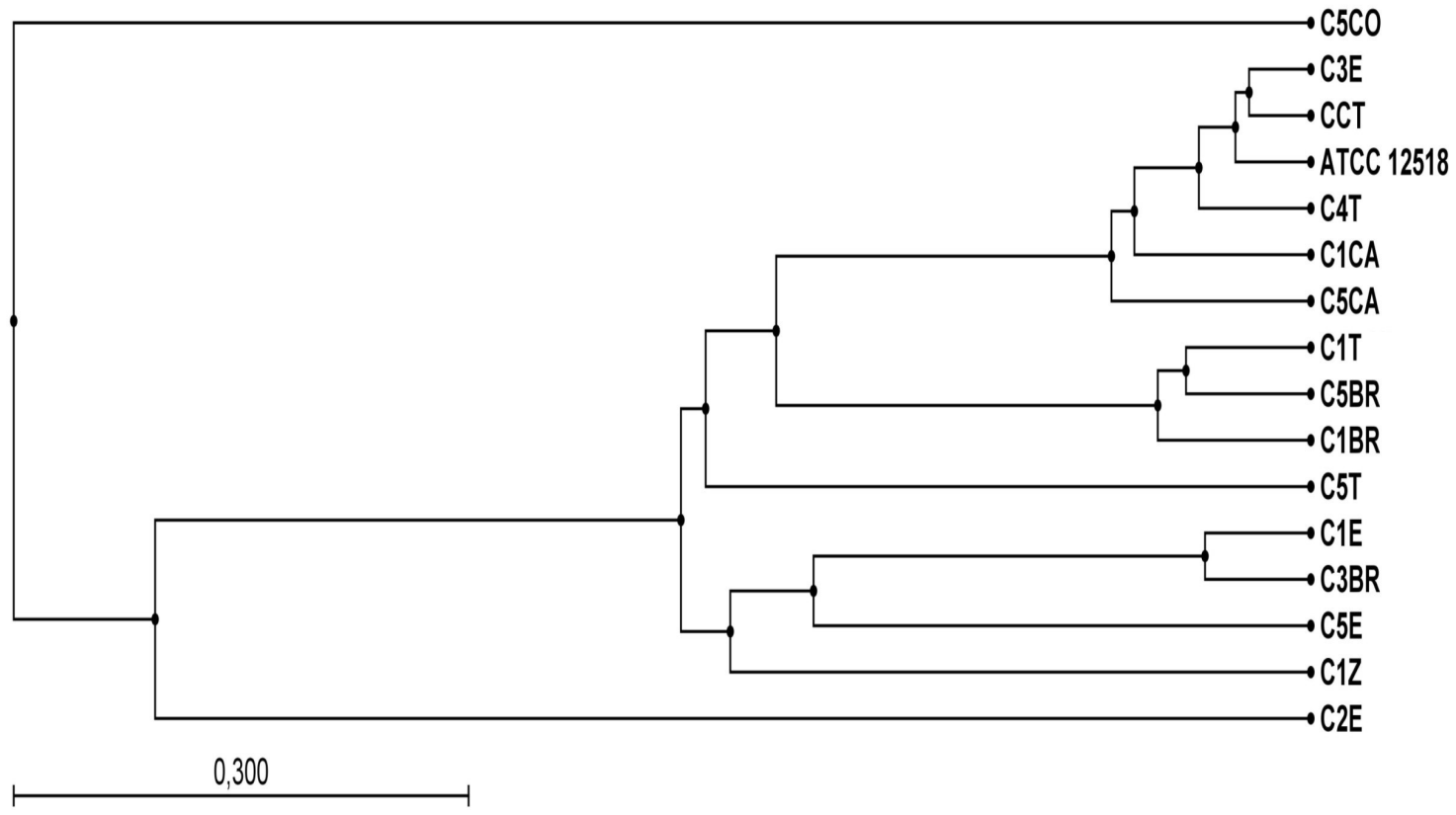

Figure 5. UPGMA for aligned sequences obtained with primers Y1-Y2 in each of the FNFB isolates from vegetable-grown soils, using Combined Workbench ${ }^{\circledR}$ v.3.6.1 software for Windows ${ }^{\circledR}$.

\section{DISCUSSION}

Azotobacter species are found in agricultural soils playing different beneficial roles: atmospheric nitrogen fixation, production of phytohormones, degradation of toxic compounds $(7,16)$ and driving the ecological balance in agro-ecosystems. For the isolation and molecular characterization of FNFB of the genus Azotobacter we sampled soils from different organic vegetable cultures located in Boyacá-Colombia, fertilized with considerable amounts of organic matter and phosphates that benefit the proliferation of FNFB as reported by Gordon (13) and Tsain et al. (37) and without nitrogen fertilizers in the rotation scheme that could inhibit the growth of Azotobacter species (3). FNFB were recovered in free nitrogen AshbySucrose agar (4) and A. chrococcum in Ashby agar with mannitol or benzoate (31). Benzoate is used as a carbon source by $A$. chrococcum, which uses the $\beta$-ketoadipate pathway to convert it into succinate. Succinate is introduced into the respiratory chain by means of the flavine-dependent system and the production of melanines, which are related to the colony pigmentation $(4,7)$. In addition, some important microelements such as iron and molybdenum are necessary for nitrogen fixation (18). Carrot-grown soils presented the lowest percentage of FNFB recovery $(31.3 \%)$, possibly due to its low $\mathrm{pH}(6.25)$, while for other soils the recovery was between $35 \%$ and $45 \%$. Although most isolates displayed the characteristic colony morphology of the genus Azotobacter, some presented transparent, glistening, shining, 2-5mm in diameter colonies, similar to the described ones for other FNFB such as Beijerinckia and Azospirillum (Figure 1G) (17, 34), which renders colony identification based on morphology a difficult task sometimes producing ambiguous results. Isolates $\mathrm{C} 5 \mathrm{CA}$ and $\mathrm{C} 1 \mathrm{Z}$ formed the characteristic cysts of Azotobacter (Figure 1C). According to Hitchins and Sadoff (15) cysts can be formed by the action of the calcium ion present in the Ashby agar after the exponential phase of growth or under adverse conditions due to the lack of nutrients. These structures are characteristic of Beijerinckia although unlike as in Azotobacter, 
in this case they do not appear forming pairs. An important characteristic of Azotobacter is the Gram-negative bacillary morphology, with cells between $2 \mu \mathrm{m}$ and $4 \mu \mathrm{m}$ in diameter (Figure 1D). Some isolates presented this morphology, while others consisted of small Gram-negative bacilli but with a morphology very similar to that displayed by Azospirillum, Beijerinckia, Herbaspirillum and Derxia (Figure 1E). However, it is known that Azotobacter is a pleiomorphic microorganism (4). In general, morphological identification and characterization are not necessarily useful in defining the genus as it was the case of isolates $\mathrm{C} 3 \mathrm{BR}$ and $\mathrm{C} 5 \mathrm{BR}$, which exhibited morphological characteristics similar to those reported for Azotobacter besides growing in nitrogen-free culture media but the molecular identification revealed that they do not belong to that genus. It has been reported that Azotobacter has the capacity to produce soluble pigments (1, 4), this can be a useful tool in the characterization of some Azotobacter species. Brown or black pigmentation in the Ashby-Benzoate agar allowed in this study the differentiation between A. chroococcum and A. nigricans (22). Isolates C1CO, C5E, C1T, C3T and C5T exhibited morphological traits and similar pigmentation to those displayed by A. chroococcum and A. nigricans (Figure $1 \mathrm{H}$ and Table 1). On the another side, isolates $\mathrm{C} 3 \mathrm{CA}$ and $\mathrm{C} 4 \mathrm{E}$ presented colonies with brown-yellow pigmentation, Gram-negative bacilli, and catalase and oxidase negative tests, suggesting that they can be aerobic FNFB that do not belong to the genus Azotobacter. In the biochemical identification, tests allowing the differentiation between genera and species were used. An example is that A. vinelandii is the only species capable of assimilating ramnose and using it as carbon source. In addition, all Azotobacter species have the capacity to produce oxidases and catalases for the protection of their nitrogenase. Universal primers (Y1-Y3) have been used in FNFB 16S rDNA amplification (2, 17, 20) although not specific for the genus Azotobacter. FNFB characterization can be done based on several different genes coding for many functions, as is the case of the gene nif that codifies the nitrogenase enzyme which drives the atmospheric nitrogen fixation $(21,26)$, in this work a partial sequence of nif $\mathrm{H}$ gene was amplified in several isolates including in the tree groups of ARDRA (data not shown). Nevertheless, both the 16S rDNA characteristics and its vertical transmission render this gene as an excellent molecular marker $(23,39)$. ARDRA is a molecular technique that allows establishing phylogenetic relationships between individuals. The enzymes used must generate high levels of polymorphism for specific groups to facilitate the detection of intra or inter-specific significant differences (14). The comparison between ARDRA and in silico analysis revealed that ARDRA is highly useful in establishing phylogenetic relationships between isolates and in clarifying the taxonomy. In general, the percentages of polymorphism of enzymes used in this work were relatively high, $16.5 \%$ on average, and similar to those reported by Aquilanti et al. (2) who obtained polymorphisms of $22 \%, 23 \%$ and $16 \%$ for AluI, HpaII and RsaI, respectively. A directly proportional relationship was demonstrated between the percentages of polymorphism and the ribotypes produced. UPGMA showed three main groups of similarity (Figure 3). We noted that group I isolates are found only in crop-grown soils located in Sogamoso, whereas group II and III isolates occur in cropgrown soils in both localities. Based solely on soil characteristics and the grown crops, clustering may differ from that one obtained with ARDRA. On the other hand, there was no relationship between the groups and the $\mathrm{pH}$ of crop-grown soils, although most isolates of group II were recovered in $\mathrm{pH}$ with values between 7.06 and 7.44. C5T and C1Z always showed irregular patterns for each enzyme and isolate C5E displayed a unique band with RsaI (Figure 2); these unique bands are particularly important since they can be useful for designing specific primers. When comparing the patterns generated in ARDRA with those obtained from the in silico restriction, a great consistency between number of bands and their corresponding molecular weights was observed in some cases. In other cases, this consistency results only for one or 
two enzymes. Inconsistencies could be due to the fact that the lengths of some of the GenBank 16S rDNA sequences do not fully match with the lengths of the sequences of our isolates, probably because the primers used differed from ours. By this reason the molecular weights of the bands could differ by a few base pairs, especially in fragments of the flanking regions of the gene, considering as similar those bands that differed by 15-25 bp. On the other hand, in some isolates the presence of bands of greater molecular weights was observed after the digestion, suggesting that some copies of the gene were not completely digested. Isolates of group I of the ARDRA (Figure 3) showed restriction patterns similar to those obtained from the sequences of Azotobacter species used in the in silico restriction, whereas the majority of isolates of group II did not show this similarity. With respect to isolates of group III, a special finding was isolate C5T that produced patterns identical to A. chroococcum (accession number AY353708). In general, the BLASTn analysis carried out with partial sequences of the $16 \mathrm{~S}$ rDNA gene obtained from every isolate revealed for group I similarity values between $74 \%$ and $84 \%$ with sequences of $A$. vinelandii; isolate C5CA showed a similarity of $78 \%$ (EF620439). Strain C5CO showed a similarity of 91\% with A. nigricans, confirming its preliminary identification. Regarding isolates of group III from ARDRA, isolate C5T showed a similarity of $99 \%$ with A. chroococcum (AY353708). In conclusion, from the 15 isolates obtained from vegetablegrown fields, 14 exhibited phenotypical similarity with species of the genus Azotobacter and 13 showed restriction patterns similar to the ones obtained with the sequences of Azotobacter in the in silico restriction. Isolate C5T obtained from a tomatogrown field (Lycopersicon esculentum) could be identified as A. chroococcum. It is important to note that the short length of the sequences analyzed with BLASTn did not suffice to obtain a clarifying view of the taxonomic position of the majority of isolates. However, ARDRA proved to be a molecular tool that allows the identification of interspecific ribotypes of FNFB using a few polymorphic enzymes. The analysis of diversity is an important factor in the measurement of quality of agricultural soils. On the other hand, it is necessary to design species-specific primers for the genus Azotobacter because of its large importance as atmospheric nitrogen fixing and plant growth promoting rhizobacteria.

\section{ACKNOWLEDGMENT}

This research was supported by the International Federation of Catholic Universities (CIC-FIUC). We thank the Environmental Biotechnology Unit and the Plant Biotechnology Unit of the Pontificia Universidad Javeriana for their collaboration.

\section{REFERENCES}

1. Aquilanti, L.; Favilli, F.; Clemeti, F. (2004). Comparison of different strategies for isolation and preliminary identification of Azotobacter from soil samples. Soil. Biol. Biochem. 36, 1475-1483.

2. Aquilanti, L.; Mannazzu, I.; Papa, R.; Cavalca, L.; Clementi, F. (2004). Amplified ribosomal DNA restriction analysis for the characterization of Azotobacteraceae: a contribution to the study of these free-living nitrogen-fixing bacteria. J. Microbiol. Methods. 57, 197-206.

3. Balandreau, J. (1986). Ecological factors and adaptive processes in N2fixing bacterial populations of the plant environment. Plant Soil. 90, 7380.

4. Becking, J. (2006). The family Azotobacteraceae. Prokaryotes. 6, 759783.

5. Benson, D.A.; Karsch, I.; Lipman, D.J.; Ostell, J.; Rapp, B.A.; Wheeler, D.L. (2003). GenBank. Nucleic. Acids. Res. 31, 23-27.

6. Borda, D.; Pardo, J.M. (2008). Determinación de la influencia de materia orgánica y Azotobacter spp. en un cultivo de Stevia rebaudiana. B. Bogotá, Colombia, 125p. (Microbiology Undergraduate. Dissertation. Science Faculty. Pontificia Javeriana University).

7. Castillo, J. (2005). Evaluación de la degradación de endosulfan por Azotobacter chroococcum y determinación del efecto plaguicida sobre la fijación biológica de nitrógeno y sobre la producción de auxinas. Bogotá, Colombia, 121p. (Microbiology Undergraduate. Dissertation. Science Faculty. Pontificia Javeriana University).

8. Cuesta, A. (2006). Estrategias de cultivo en la producción de alginatos por Azotobacter vinelandii. Medellín, Colombia, 105p. (M.Sc. Dissertation. National University of Colombia). 
9. Faccini, G.; Garzon, S. (1996). Evaluación del efecto de un inóculo dual de bacterias solubilizadoras de fosfato y Azotobacter chroococcum en el cultivo de papa "criolla” yema de huevo (Solanum phureja). Bogotá, Colombia, 97p. (Bacteriology Undergraduate. Dissertation. Science Faculty. Pontificia Javeriana University).

10. Felsenstein, J. (1985). Confidence limits on phylogenies: an approachusing the bootstrap. Evolution. 39, 783-791.

11. Galindo, T.; Polania, J.; Sánchez, J.; Moreno, N.; Vanegas, J.; Holgin, G. (2006). Efecto de inoculantes biológicos en el crecimiento de manglar y Citrullus vulgaris. San Andrés Isla, Colombia. Acta. Biol. Colomb. 11, $83-97$.

12. Garg, S.; Bhatnagar, A.; Kalla, A.; Narula, N. (2001). In vitro nitrogen fixation, phosphate solubilization, survival and nutrient release by Azotobacter strains in an aquatic system. Bioresour. Technol. 80, 101109.

13. Gordon, J. (1981). Introduction to the nitrogen fixing prokaryotes. In: Starr, M.P., Stolp, H., Prüper, N.G., Balows, A., Schlegel, H.G. (eds.), The Prokaryotes: A Handbook on Habitats, Isolation and Identification of Bacteria. Springer, Heidelberg, Germany p. 781-794.

14. Heyndrickx, M.; Vauterin, L.; Bañadme, P.; Kesters, P.; De Vos, P. (1996). Applicability of combined amplified ribosomal DNA restriction analysis (ARDRA) patterns in bacterial phylogeny and taxonomy. $J$. Microbiol. Methods. 26, 247-259.

15. Hitchins, V.; Sadoff, H. (1973). Sequential metabolic events during encystment of Azotobacter vinelandii. J. Bacteriol. 113, 1273-1279.

16. Juárez, B.; Martínez, M.; González, J. (2004). Growth of Azotobacter chroococcum in chemically defined media containing p-hydroxybenzoic acid and protocatechuic acid. Chemosphere. 59, 1361-1365

17. Junior, F.; Silva, M.; Texeira, K.; Urquiaga, S.; Reis, M. (2004). Identification of Azospirillum amazonense isolates associated to Brachiaria spp. at different stages and growth conditions and bacterial plant hormone production. Rev. Bras. Ciênc Solo. 28, 103-113.

18. Kumar, U.; Narula, N. (1999). Solubilization of inorganic phosphate and grown emergencia of wheats as affected by Azotobacter chroococcum mutants. Biol. Fertil. Soils. 28, 301-305.

19. Kumar, V.; Singh, K. (2001). Enriching vermicompost by nitrogen fixing and phosphate solubilizing bacteria. Bioresour. Technol. 76, 173-175.

20. Magalhães, L.; Maltempi, De Souza.; Baler, O.; Baldani, J.; Dobereiner, J.; De Oliveira, F. (2001). 16S ribosomal DNA characterization of nitrogen-fixing bacteria isolated from Banana (Musa spp.) and Pineapple (Ananas comosus (L.) Merril). Appl. Environ. Microbiol. 67, 2375-2379.

21. Mantilla, J. (2008). Distribución y capacidad fijadora de nitrógeno de bacterias diazótrofos aisladas en suelos del sur del trapecio Colombiano.155p. (M.Sc. Dissertation. Science Faculty. Pontificia Javeriana University).

22. Martyniuk, S.; Martyniuk, M. (2002). Occurrence of Azotobacter spp. in some polish soils. Pol. J. Environ. Stud. 12, 371-374.

23. Nogales, B. (2005). Microbiología del suelo en la era de la biología molecular: Descubriendo la punta del iceberg. Ecosistemas. 2, 1-10.

24. Pandey, A.; Kumar, S. (1990). Inhibitory effects of Azotobacter chroococcum and Azospirillum brasiliense on a range of rhizosphere fungi. Indian J. Exp. Biol. 28, 52-54.

25. Pandey, A.; Sharma, E.; Palni, L. (1998). Influence of bacterial inoculation on maize in upland farming systems of the Sikkim Himalaya. Soil. Biol. Biochem. 30, 379-384.

26. Roesch, L.; Olivares, F.; Pereira, L.; Selbach, P.; Saccol, De Sae.; Oliveira, F. (2006). Characterization of diazotrophic bacteria associated with maize: effect of plant genotype, ontogeny and nitrogen-supply. World. J. Microbiol.Biotechnol. 22, 967-974.

27. Rohlf, F.J. (1993). NTSYS. PC. Numerical taxonomy and multivariate analysis system, Version 1.8 Applied Biostatistics. New York. USA.

28. Sabra, W.; Zeng, A.; Deckwer, W. (2001). Bacterial alginate: physiology, product quality and process aspects. Appl. Microbiol. Biotechnol. 56, 315-325.

29. Santana, M.; Vásquez, C. (2002). Evaluación de cepas de Azotobacter spp. y de bacterias solubilizadoras de fosfato (BFS), como biofertilizante mixto en cultivo de crisantemo (Chrysanthemum morifolium var. Regal Suerte). Bogotá, Colombia. 94p. (Microbiology Undergraduate. Dissesrtation. Science Faculty. Pontificia Javeriana University).

30. Salmeron, V.; Martinez, M.V.; Gonzalez, J. (1990). Nitrogen fixation and production of auxins, gibberellins and cytokinin by Azotobacter chroococcum strain isolated from root of Zea mays in presence of insoluble phosphate. Chemosphere. 20, 417-422.

31. Saribay, G. (2003). Growth and nitrogen fixation dynamics of Azotobacter chroococcum nitrogen-free and own containing medium. Ankara, Turkia, 45p. (M.Sc. Dissertation. The Middle East Technical University).

32. Setubal, J.; Dos Santos, P.; Goldman, B.; Ertesvåg, H.; Espin, G.; Rubio, L.; Valla, S.; Almeida, N.; Balasubramanian, D.; Cromes, L.; Curatti, L.; Du, Z.; Godsy, E.; Goodner, B.; Hellner-Burris, K.; Hernandez, J.; Houmiel, K.; Imperial, J.; Kennedy, C.; Larson, T.; Latreille, P.; Ligon, L.; Lu, J.; Mærk, M.; Miller, N.; Norton, S.; O'Carroll, I.; Paulsen, I.; Raulfs, E.; Roemer, R.; Rosser, J.; Segura, D.; Slater, S.; Stricklin, S.; Studholme, D.; Sun, J.; Viana, C.; Wallin, E.; Wang, B.; Wheeler, C.; Zhu, H.; Dean, D.; Dixon, R.; Wood. D. (2009). Genome sequence of Azotobacter vinelandii, an obligate aerobe specialized to support diverse anaerobic metabolic processes. J. Bacteriol. 191, 4534-4545.

33. Sudhir, U.; Meshram.; Jager, G. (1983). Antagonism of Azotobacter chroococcum isolates to Rhizoctonia solani. Eur. J. Plant Phatol. 89, 191-197.

34. Tchan, Y.T.; New, P.B. (1984). Genus I Azotobacter, Beijerinck 1901, 567AL. In: Krieg, N.R., Holt, J.G. (eds.). Bergey's Manual of 
Determinative Bacteriology, vol. 1. Williams \& Wilkins, Baltimore, USA, p. 220-229.

35. Tejera, N.; Lluch, C.; Martínez, M.; González, J. (2005). Isolation and characterization of Azotobacter and Azospirillum strains from the sugarcane rhizosphere. Plant Soil. 27, 223-232.

36. Torres, M.; Valencia, S.; Bernal, J.; Martínez, P. (2000). Isolation of Enterobacteria, Azotobacter sp. and Pseudomonas sp., producers of indole-3-acetic acid and siderophores, from Colombian rice rhizosphere. Rev. Latin. Microbiol. 42, 171-176.

37. Tsain, J.; Aladegbami, S.; Vela, G. (1979). Phosphate-limited culture of
Azotobacter vinelandii. J. Bacteriol. 139, 639-645.

38. Van Lierop, W. (1981). Conversion of organic soil $\mathrm{pH}$ values measured in water, $0.01 \mathrm{M} \mathrm{CaCl} 2$ or $1 \mathrm{~N} \mathrm{KCl.} \mathrm{Can.} \mathrm{J.} \mathrm{Soil.} \mathrm{Sci.} \mathrm{6,} \mathrm{577-579.}$

39. Weisburg, W.; Barns, M.; Pelleteried, D.; Lane, D. (1991). 16S Ribosomal DNA amplification for the phylogenetic study. J. Bacteriol. 173, 697-703.

40. Young, J.; Downer, H.; Eardly, B. (1991). Phylogeny of the phototrophic Rhizobium Strain BTAil by polymerase chain reaction-based sequencing of a16S rRNA gene segment. J. Bacteriol. 173, 2271-2277. 